\title{
Consensus
}

Volume 25

Issue 2 The Arts and the Church

Article 12

11-1-1999

\section{The invention of ancient Israel: the silencing of Palestinian history}

Roger W. Uitti

Follow this and additional works at: http://scholars.wlu.ca/consensus

\section{Recommended Citation}

Uitti, Roger W. (1999) "The invention of ancient Israel: the silencing of Palestinian history," Consensus: Vol. 25 : Iss. 2 , Article 12. Available at: http://scholars.wlu.ca/consensus/vol25/iss2/12

This Book Reviews is brought to you for free and open access by Scholars Commons @ Laurier. It has been accepted for inclusion in Consensus by an authorized editor of Scholars Commons @ Laurier. For more information, please contact scholarscommons@wlu.ca. 


\section{The Invention of Ancient Israel: The Silencing of Palestinian History}

Keith W. Whitelam

London and New York, NY: Routledge, 1997

viii +281 pages, \$22.99 US Paperback

This monograph is a sobering reminder of the subtle biases that attend all historical writing and reconstruction. Its author, Keith W. Whitelam, professor of religious studies and department head at the University of Stirling, holds that the present customary historical delineation of ancient Israel is a scholarly invention, essentially a self-serving and conscious enterprise that has effectively snuffed out Palestine's true past because of a desire to give support to biblical and Christian preoccupations as well as affirmation to the rise and legitimacy of the modern state of Israel:

For the last two centuries, Palestinian history has become one of the many "excluded" histories as a result of the stranglehold on the study of Palestine and the ancient Near East which biblical specialists, historians, and archaeologists, have exerted. The consequence of this has been that Palestinian history has been denied a place in Western academic discourse. Europe's strategic concern with Palestine coincided with its quest for the roots of its own civilization as identified with ancient Israel and the Bible. Biblical scholars, accepting, in broad outline, the construction of the past offered by biblical traditions began the search for Israel's physical presence among the monuments and ruins of the land. What they found, or were predisposed to find, was an Israel which resembled their own nation states: Israel was presented as an incipient nation state in search of a national homeland in which to express its national consciousness. Throughout the present century, this projection of ancient Israel has come to dominate and control the Late Bronze and Iron Ages. It is a representation of the past which was given added urgency and authority with the rise of the Zionist movement, an essentially European enterprise, whose own history was seen to mirror ancient Israel's conquest of the land followed by the founding of a nation state which soon dominated the region (223).

To date, Whitelam argues, the histories of the land of Palestine (Albright, Alt, Bright, Finkelstein, Gottwald, Hayes, Mendenhall, Miller, Soggin, Wright) and even those which have consciously attempted to distance themselves from biblical and Israeli interests (Ahlström, Lemche, Coote, Thompson), have turned out essentially to be "histories of Israel". There has been little effort whatsoever to define the territory under scrutiny in broader cultural terms. Thus this monograph lays out a compelling case for the one-sidedness of Christian and Israeli historiography to the present. 
However, one wishes the author would have spent some time and space spelling out what a truly "Palestinian" history of the area - freed from the confining restraints of biblical, Israelite, and Israeli self-congratulations - would actually look like. The present volume is strong on the critique of the past and the present but not very strong on what the future should be. As such the work is more a prolegomenon and strident call to stop what we are doing to "Palestinians" than a how to go about doing the new and more correct thing. Hopefully such a second volume is not too far off, although its production may not be as easy as one might think in view of the nature of the evidence and resources available for it.

In conclusion, this review will have accomplished its objective should you the reader be encouraged to read this paperback. Although this study gives focus to particular voices silenced in a specific part of the world, the broader methodological questions raised might inspire us to revisit the histories of other marginalized, possibly misrepresented, or even unrepresented peoples much closer to us.

Roger W. Uitti

Lutheran Theological Seminary

\section{The Gospel of John in the Light of the Old Testament \\ Claus Westermann}

Translated by Siegfried Schatzmann

Massachusetts: Hendrickson Publishers, 1998

103 pages, \$15.99 Softcover

When reading this short commentary on the Gospel of John, I felt that I was wading into a large and complex debate among New Testament scholars. This debate centres on the degree of Gnostic influence on the Gospel. Westermann, an Old Testament scholar, takes a brief but deep plunge into the sterile yet potent waters of redaction and form criticism. He implies false dichotomy in the question: Do we interpret the Gospel as Gnostic writing, or as a Christian writing, "in which Gnostic elements are not meant in a Gnostic sense?"

Instead, one criterion that explains the contrast between Gnostic and nonGnostic elements in the Gospel, asserts Westermann, "is how the Gnostic and the non-Gnostic motifs relate to the Old Testament." His argument is built on the understanding that the Gospel is divided into two layers of redaction: a later layer and an earlier layer.

According to Westermann, there is only one component of the Gospel that 